\title{
Screening and Biochemical Characterization of PHB Producing Bacterium Isolated from Costal Region of Andhra Pradesh
}

\author{
Ranganadha Reddy Aluru \\ Department of Biotechnology, Vignan’s Foundation for Science, Technology \& Research, Guntur 522 213, India \\ Corresponding Author Email: arr_bt@vignan.ac.in
}

https://doi.org/10.18280/eesrj.070304

Received: 20 June 2020

Accepted: 25 August 2020

\section{Keywords:}

biopolymer, Bacillus

Polyhydroxtbutyratye, FT-IR, DSC

\begin{abstract}
Biopolymers and their composites have been massively investigated in recent years for multiple applications especially in environmental medical and pharmaceutical fields. A thermoplastic that is both biodegradable and environmental friendly, as well as biocompatible is PHB. PHB is an intracellular granule, which is a carbon and energy reservoir for the bacteria under starvation or stress conditions. In the present work, we focused on identification of potential PHB (Polyhydroxybutyrate) producing bacterial strains from sewage soil of coastal region of Andhra Pradesh. Five bacterial isolates were identified through Sudan Black staining, out of which RR02 was observed to be potential for PHB production. Further, PHB extraction was performed by solvent extraction method. The extracted sample was characterized by FTIR, melting temperature Tm, was determined by DSC and then, compared with standard PHB for confirmation of quality. Biochemical characterization was also performed for preliminary identification of the bacterial isolate. Based on the study it was found to be Bacillus sp.
\end{abstract}

\section{INTRODUCTION}

Industrial growth and anthropogenic development over the past century have continuously increased the dependency of humans on plastics. Packaging material, building and construction, transportation, medical and health, electrical and electronics, agriculture, sports and leisure products are some of the many ways in which human population utilize plastics [1-4]. Enormous amounts of waste, which is difficult to decompose, and green house gases are generated by both the production and after life remediation of plastics, which cause various kinds of health hazard problems in humans [5]. Plastic is naturally resistant to degradation due to the molecular size which is up to 1, 50,000 Dalton. Diminishing oil resources is caused directly by the consumption of petrochemical based plastics. In order to displace this ever increasing use of plastic, a potential material could be bioplastic, which can be equally utilized in all applications [6-8]. It's degradability with time is the major merit of bioplastic over synthetic plastic. Bioplastics, in some cases are non immunogenic in nature and this can be utilized for designing medical implants and devices [9]. They are an important class of advanced biomaterial and consist of thermostable polyesters. The physico-chemical properties of bioplastics are similar to that of synthetic polymers, with an added advantage of being degradable under normal environmental conditions [10, 11]. A lot of interest for scientists and researchers has been created by biodegradable polymers such as PLA (Polyactic acid), PHA (Polyhyrdoxy alkanoates), PHB and Cellophane. Polyhydroxy alkanoates (PHAs) can be purified from bacteria, which have the ability to accumulate bioplastics under stress conditions in these forms $[12,13]$. PHAs are 3-ydroxy fatty acid monomers that form linear, head-to-tail polyester. PHA is normally produced as a polymer containing 103-104 monomers. This accumulates in the bacterial inclusion size of $0.2-0.5 \mu \mathrm{m}$ in diameter. In 1925, Lemoigne first discovered Poly-3hydroxybutyrate (PHB) in bacteria. PHB is a linear polyester of $\mathrm{D}(-)-3$ hydroxybutyric acid. $\mathrm{PHB}$ which is a member of the PHA family is the most widely used at industrial level for production [14, 15]. Various micro organisms such as Pseudomonas putida, Alcaligenes latus, Aeromonas hydrophila, Bacillus sps., and Ralstonia eutropha undergo nutrient imbalance conditions, like higher carbon ratio with reduced phosphorus, nitrogen and oxygen to produce the polyesters polyhydroxyalkanoates (PHAs) [16-19]. Depending upon the various groups and their position on the main chain, PHA consists of different classes. PHAs can be found as homopolymers or as co-polymer and have approximately 150 different constituents [20]. The current study involved screening of bacteria that produce PHB and the characterization of PHB which is produced for the quality.

\section{MATERIALS AND METHODS}

\subsection{Sample collection}

Soil samples were collected from different sites of sea coast situated at costal area of Guntur (Costal Region of Andhrapradesh). The samples were stored in sterile plastic bags at $4^{\circ} \mathrm{C}$ and were transferred to laboratory.

\subsection{Isolation of PHB producing bacteria}

1 gram of costal soil sample was collected from sea coast of Guntur, Andhrapradesh. Pure colonies of bacterial isolates were obtained by serial dilution pour plate technique on nutrient agar medium using L shaped spreader. All the 
petriplates were incubated at $37^{\circ} \mathrm{C}$ for $24-48$ hours and bacterial colonies with unique characteristic features were maintained as pure cultures on agar slants and preserved at $4{ }^{\circ} \mathrm{C}$.

\subsection{Morphological analysis of bacterial isolates}

Pure bacterial colonies were characterized for colour, form, elevation, margin etc. Bacterial isolates were morphologically analyzed on the basis of staining and cell morphology using microscope.

\subsubsection{Simple staining}

The simple staining of isolate was done and analyzed for the cell size, arrangement, form, shape and pattern of the isolated strain. Methylene blue was used as simple staining dye. Smear was prepared on glass slides, heat fixed and were stained with 2-3 drops of methylene blue. Dye was washed with distilled water. The slide was placed under $100 \mathrm{X}$ microscope for the visualization of cell shape and cell arrangement [21, 22].

\subsection{Screening for PHB positive colonies}

The isolates were further screened for PHB accumulation by Sudan Black B staining.

\subsubsection{Sudan Black B staining}

Isolated strains were smeared on glass slide, heat fixed. Later, the smear was stained with Sudan Black B solution (Sudan Black B $0.3 \mathrm{gm}$ in $70 \%$ ethyl alcohol $100 \mathrm{ml}$ ) and air dried, washed with alcohol, further safranin was added, 2-3 drops on the smear for 20 seconds and washed with distilled water. The slide was placed under 100x microscope (fluorescence microscope) for visualization. The bacterial cytoplasm was stained light pink and lipid granules were stained black [23].

\subsection{PHB extraction from bacterial isolates}

PHB extraction from bacterial isolates was carried by centrifugation of $10 \mathrm{~mL}$ of bacterial culture $(10000 \mathrm{rpm} / 15$ min.) and pellet was digested with sodium solution at $37^{\circ} \mathrm{C}$ for $1 \mathrm{hrs}$. The mixture was further centrifuged at $5000 \mathrm{rpm}$ for 15 min and washed with distilled phosphate buffer saline, water, acetone and methanol respectively. After washing, the pellet was dissolved in $5 \mathrm{ml}$ of boiling chloroform and kept for complete evaporation to obtain PHB crystal [24].

\subsection{Identification of PHB sample and PHB assay}

The sample was identified by Polyhydroxybutyrate assay. Polyhydroxybutyrate assay was performed as per the standard method of Law and Slepecky [25].

\subsection{Characterization of PHB}

The extracted PHB was characterized by FTIR and DSC analysis.

\subsubsection{FTIR analysis}

FTIR is a powerful approach that is used to identify organic, polymer and inorganic materials. Infrared light for scanning samples and for observing chemical properties are used by the FTIR analytical technique. FTIR transmits infrared radiation between 10,000 and $100 \mathrm{~cm}^{-1}$, which receive and pass through such radiation. The radiation absorbed is converted into rotating or vibrational energy by the sample. The received image on the sensor generally shows a profile of the sample, from $4000 \mathrm{~cm}^{-1}$ to $400 \mathrm{~cm}^{-1}$. 1mg of the PHB sample and $10 \mathrm{mg}$ of spectral pure anhydrous potassium bromide crystal was formed into pellet for IR analysis.

\subsubsection{DSC analysis}

The crystallization temperature $(\mathrm{Tc})$, melting temperature ( $\mathrm{Tm})$, and glass transition temperature $(\mathrm{Tg})$ were determined by using Differential Scanning Calorimeter. Extracted Biopolymer sample was encapsulated in aluminium crucible and heated in a temperature range from $-50^{\circ} \mathrm{C}$ to $400^{\circ} \mathrm{C}$ at the rate of $10{ }^{\circ} \mathrm{C} / \mathrm{min}$. Melting temperature was recorded at the peak of the melting endotherm [26].

\section{RESULTS AND DISCUSSION}

\subsection{Isolation and screening of PHB producing colonies}

Out of 30 bacterial isolates screened for PHB production, 05 isolates screened positive after preliminary screening. Bacterial isolates that appeared bluish white under UV were selected as potential PHB producers. Among the 05 isolates which were subjected to secondary screening isolate RR02 was highly potential for PHB production as indicated in Table 1 and hence isolate RR02 was selected for further studies. Andhrapradesh has a vast coastal region of $1000 \mathrm{kms}$, Guntur region was explored for collecting soil sample. In this scenario in our study Bacillus sp. RR02 strain which was isolated successfully from coastal region of Guntur is highly potential for PHB production as shown in Figure 1.

Table 1. PHB yield from isolated bacterial colonies

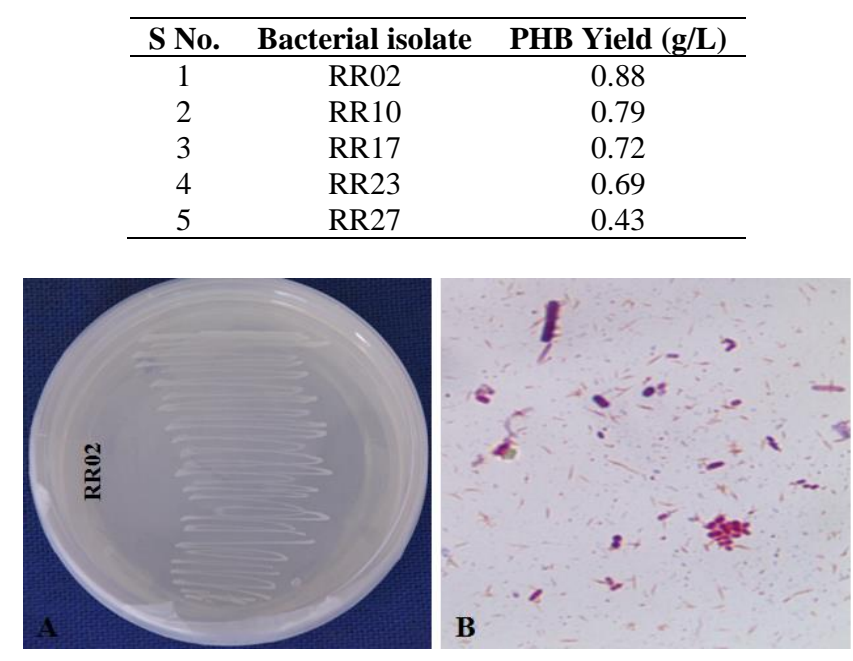

Figure 1. PHB producing positive colony a) pure colony of RR02 b) Staining

\subsection{Screening of isolate RR02 by Sudan Black B}

Smear of isolate RR02 was prepared on glass slide and stained with Sudan Black B (0.3 gm in $100 \mathrm{ml}$ of $70 \%$ ethanol). Results were observed under Olympus microscope at 100X as shown in Figure 2. 

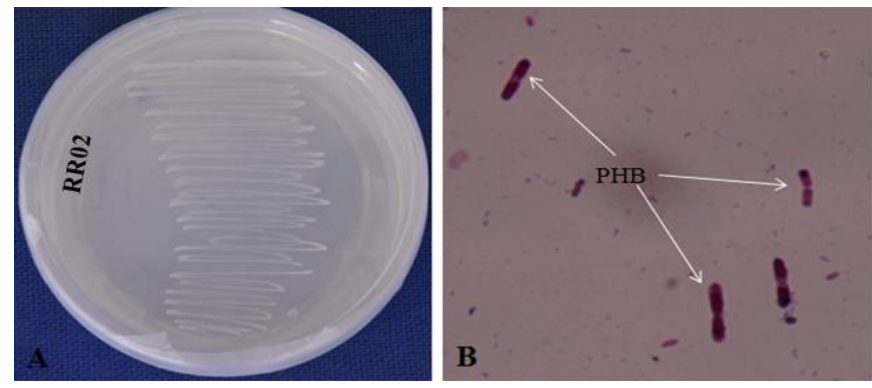

Figure 2. PHB positive Colony a) bacterial isolate RR02 b) Sudan Black B staining

\subsection{PHB assay by Law and Slepecky method}

PHB assay for the bacterial isolates was performed by using the standard Law and Slepecky method. The bacterial isolates viz., RR02, RR10, RR17, RR23 and RR27 showed considerable amount of PHB accumulation as shown in Table1 Whereas, other isolates comparably yielded less amount of PHB. The bacterial isolate RR02 was choosen for further studies as it produced maximum yeild of PHB as compared to other bacterial isolates. PHB assay using concentrated $\mathrm{H}_{2} \mathrm{SO}_{4}$ is based upon quantitative conversion of PHB to crotonic acid under boiling conditions (Figure 3). Crotonic acid has got lambda max at $235 \mathrm{~nm}$ when $\mathrm{H}_{2} \mathrm{SO}_{4}$ is used as a solvent and it permits an accurate quantification of PHB. Biochemical characterization studies of the bacterial isolate revealed positive for PHB production.

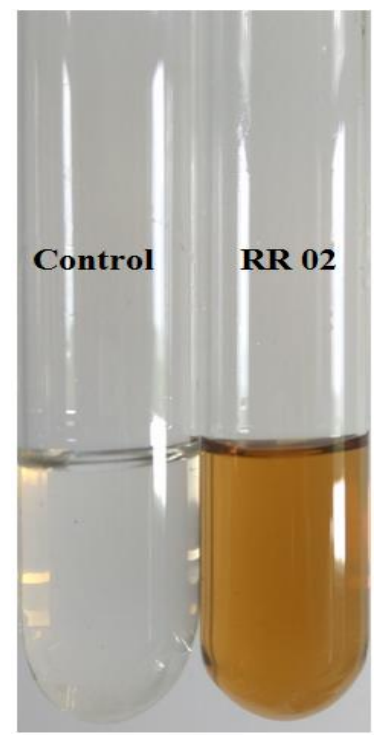

Figure 3. PHB assay of bacterial isolate RR02 by Law and Slepecky method

\subsection{Extraction of PHB}

The bacterial isolate RR02 was incubated in rotary shaker for 3-7 days for mass growth at $37^{\circ} \mathrm{C}$. After 7 days of incubation the medium appeared turbid. Then the sample was extracted from the turbid medium using soxhlet apparatus. Crude PHB was extracted in centrifuge tubes as a pellet and was dried using hot air woven. Earlier researchers reported the accumulation of PHB granules by a large number of gram positive and gram negative bacterial species [27-32].

\subsection{PHB characterization}

\subsubsection{FT-IR Analysis}

FT-IR is used for characterization of isolated Poly-3hydroxybutyrate from bacterial isolate [33]. FTIR spectrum of Bacillus sp RR02 revealed the absorption peaks at $3416 \mathrm{~cm}^{-1}$ and $3333 \mathrm{~cm}^{-1}$ (Figure 4) denote terminal hydroxyl group ($\mathrm{OH})$. The absorption band at $3020 \mathrm{~cm}^{-1}$ represents methylene group. The absorption bands at 3020, 1609 and $1510 \mathrm{~cm}^{-1}$ denote the $-\mathrm{C} \equiv \mathrm{C}-, \quad-\mathrm{C}=\mathrm{C}-$ and $\mathrm{N}-\mathrm{O}$ asymmetric stretch respectively. The absorption bands at $1441 \mathrm{~cm}^{-1}$ and $1397 \mathrm{~cm}^{-1}$ denote $\mathrm{C}-\mathrm{O}$ ester bond, $\mathrm{CH}$ vibrations of $-\mathrm{CH}_{2}$ and $-\mathrm{CH}_{3}$ functional groups. The absorption bands at 1219, 1098 and $500-1000 \mathrm{~cm}^{-1}$ represents $\mathrm{C}=\mathrm{O}$ ester group, $\mathrm{C}-\mathrm{O}$ stretch and $\mathrm{OH}$ group. The FT-IR spectral results of biopolymer isolated from Bacillus sp. RR02 correlated with the earlier findings [34-36] indicating the isolated compound as PHB.

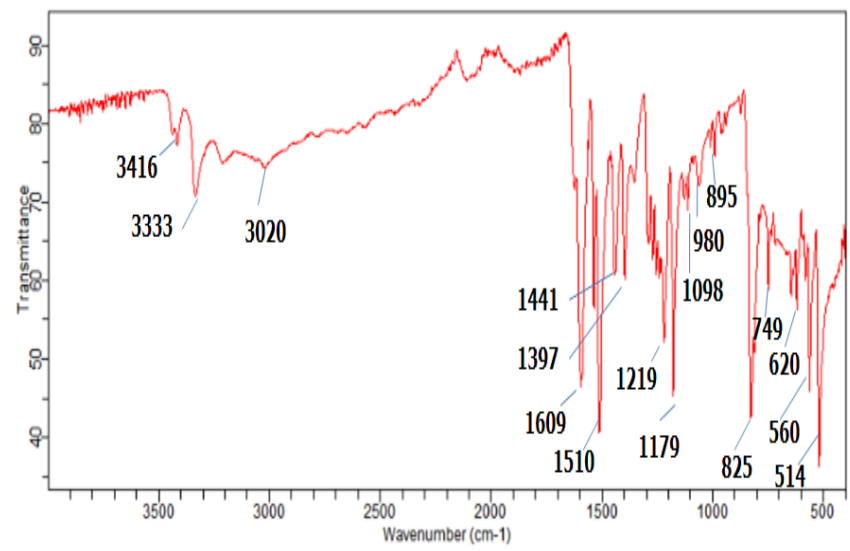

Figure 4. FTIR spectrum of powered PHB from Bacillus sp. RR02

\subsubsection{DSC Analysis}

The Differential Scanning Calorimetry thermograms (Figure 5) revealed the characteristic or DSC as shown in Figure 5 which indicated that the melting temperature Tm of PHB biopolymer is $169^{\circ} \mathrm{C}$ which was very close to melting temperature $\operatorname{Tm}\left(175^{\circ} \mathrm{C}\right)$ of the standard PHB [37-41] with an increasing temperature range from $50^{\circ} \mathrm{C}$ to $450^{\circ} \mathrm{C}$.

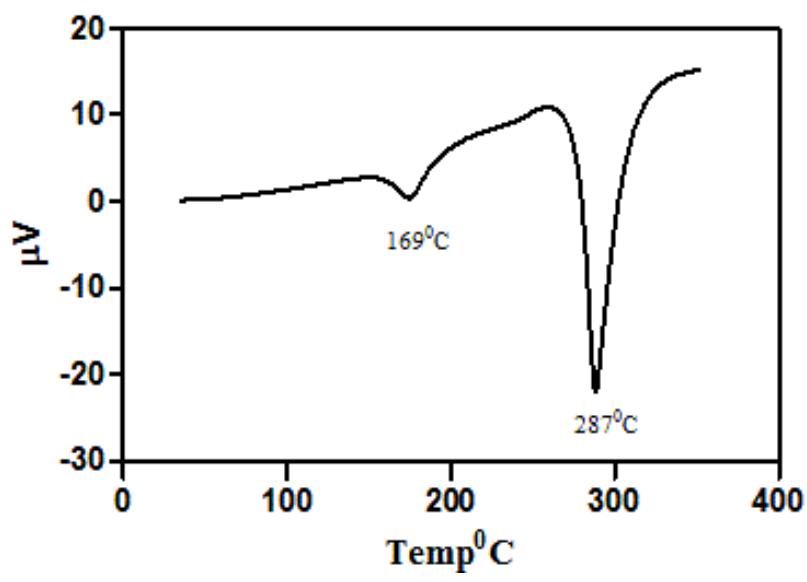

Figure 5. DSC analysis of powered PHB from Bacillus sp RR02 


\section{CONCLUSION}

In the current study, different bacterial colonies were isolated and screened from soil for the production of Polyhydroxybutyrate. The isolate Bacillus sp. RR02 producing greater amount of PHB was studied. The biopolymer produced by Bacillus sp. RRO2 was characterized by FTIR. DSC studies revealed the melting temperature Tm of biopolymer as $169^{\circ} \mathrm{C}$ which was almost similar to standard PHB. The above studies reveal the potential of Bacillus sp. RR02 as promising alternative for commercial production of Polyhyhydroxybutyrate.

\section{ACKNOWLEDGMENT}

The author acknowledges VFSTR (Deemed to be university) and DST-FIST networking facility to carry out this work.

\section{REFERENCES}

[1] Muthu, S.S., Li, Y., Hu, J.Y., Mok, P.Y., Ding, X. (2012). Eco-impact of plastic and paper shopping bags. Journal of Engineered Fibers and Fabrics, 7(1): 26-37. https://doi.org/10.1177/155892501200700103

[2] Lajeunesse, S. (2004). Plastic bags. Chemical and Engineering News, 82(38): 51.

[3] Arrieta, M.P., Samper, M.D., Aldas, M., López, J. (2017). On the use of PLA-PHB blends for sustainable food packaging applications. Materials, 10(9): 1-26. https://doi.org/10.3390/ma10091008

[4] Suriyamongkol, P., Weselake, R., Narine, S., Moloney, M., Shah, S. (2007). Biotechnological approaches for the production of polyhydroxyalkanoates in microorganisms and plants-a review. Biotechnology Advances, 25(2): $148-175$.

https://doi.org/10.1016/j.biotechadv.2006.11.007

[5] Chen, G.Q., Patel, M.K. (2012). Plastics derived from biological sources: Present and future: A technical and environmental review. Chemical Reviews, 112(4): 20822099. https://doi.org/10.1021/cr200162d

[6] Sathiyanarayanan, G., Saibaba, G., Kiran, G.S., Selvin, J. (2013). A statistical approach for optimization of polyhydroxybutyrate production by marine Bacillus subtilis MSBN17. International Journal of Biological Macromolecules, $\quad 59$ : 170-177. https://doi.org/10.1016/j.ijbiomac.2013.04.040

[7] Sindhu, R., Silviya, N., Binod, P., Pandey, A. (2013). Pentoserich hydrolysate from acid pretreated rice straw as a carbon source for the production of poly-3hydroxybutyrate. Biochemical Engineering Journal, 78: 67-72. https://doi.org/10.1016/j.bej.2012.12.015

[8] Arun, A., Arthi, R., Shanmugabalaj, V., Eyini, M. (2009). Microbial production of poly-b-ydroxybutyrate by marine microbes isolated from various marine environments. Bioresource Technology, 100(7): 23202323. https://doi.org/10.1016/j.biortech.2008.08.037

[9] Madison, L.L., Huisman, G.W. (1999). Metabolic engineering of poly (3-ydroxyalkanoates): From DNA to plastic. Microbiolology and Molecular Biology Reviews, 63(1): 21-53. https://doi.org/10.1128/MMBR.63.1.2153.1999

[10] Yousuf, R.G., Winterburn, J.B. (2016). Date seed characterisation, substrate extraction and process modelling for the production of polyhydroxybutyrate by Cupriavidus necator. Bioresource Technology, 222: 242251. https://doi.org/10.1016/j.biortech.2016.09.107

[11] Tripathi, A.D., Srivastava, S.K., Singh, R.P. (2013). Statistical optimization of physical process variables for bio-plastic (PHB) production by Alcaligenes sp. Biomass and Bioenergy, 55: 243-250. https://doi.org/10.1016/j.biombioe.2013.02.017

[12] Chen, G.Q. (2009). A microbial polyhydroxyalkanoates (PHA) based bio- and materials industry. Chemical Society Reviews, 38(8): 2434-2446. https://doi.org/10.1039/B812677C

[13] Reddy, A.R., Venkateswarulu, T.C., Indira, M., Narayana, A.V., Nagalohita, T., Sriharsha, M. (2015). Identification of membrane drug targets by subtractive genomic approach in mycoplasma pneumonia. Research Journal of Pharmacy and Technology, 8(9): 1209-1216. https://doi.org/10.5958/0974-360X.2015.00221.8

[14] Cavalheiro, J.M., de Almeida, M.C.M., Grandfils, C., Da Fonseca, M.M.R. (2009). Poly (3hydroxybutyrate) production by Cupriavidus necator using waste glycerol. Process Biochemistry, 44(5): 509-515. https://doi.org/10.1016/j.procbio.2009.01.008

[15] Lee, K.M., Gilmore, D.F. (2005). Formula- tion and process modeling of biopolymer (polyhydroxyalkanoates: PHAs) production from industrial wastes by novel crossed experimental design. Process Biochemistry, 40(1): 229-246. https://doi.org/10.1016/j.procbio.2003.12.007

[16] Anderson, A.J., Dawes, E.A. (1990). Occurrence, metabolism, metabolic role, and industrial uses of bacterial polyhydroxyalkanoates. Microbiological Reviews, 54: 450-72.

[17] Mohapatra, S., Mohanta, P.R., Sarkar, B., Daware, A., Kumar, C., Samantaraye, D.P. (2017). Production of polyhydroxyalkanoates (PHAs) by bacillus strain isolated from waste water and its biochemical characterization. Proceedings of the National Academy of Sciences, India Section B: Biological Sciences, 87(2): 459-466. https://doi.org/10.1007/s40011-015-0626-6

[18] Yung, H.Y., Brigham, C.J., Budde, C.F., Boccazzi, P., Willis, L.B., Hassan, M.I., Yusof, Z.A.M., Rha, C., Sinakey, A.J. (2010). Optimization of growth media components for polyhydroxyalkanoate (PHA) production from organic acids by Ralstonia eutropha. Applied Microbiology and Biotechnology, 87(6): 20372045. https://doi.org/10.1007/s00253-010-2699-8

[19] Hahn, S.K., Chang, Y.K., Kim, B.S., Chang, H.N. (1994). Optimization of microbial poly (3-hydroxybutyrate) recovery using dispersions of sodium hypochlorite solution and chloroform. Biotechnology and Bioengineering, 44(2): 256-261. https://doi.org/10.1002/bit.260440215

[20] Loo, C.Y., Sudesh, K. (2007). Polyhydroxyalkanoates: Bio-based microbial plastics and their properties. Malaysian Polymer Journal, 2(2): 31-57.

[21] Indira, M., Venkateswarulu, T.C., Chakravarthy, K., Reddy, A.R., Babu, D.J., Kodali, V.P. (2016). Morphological and biochemical characterization of exopolysaccharide producing bacteria isolated from dairy effluent. Journal of Pharmaceutical Sciences and Research, 8(2): 88-91.

[22] Indira, M., Venkateswarulu, T.C., Chakravarthy, K., 
Ranganadhareddy, A., Vidya Prabhakar, K. (2015). Isolation and characterization of bacteriocin producing lactic acid bacteria from diary effluent. Research Journal of Pharmacy and Technology, 8(11): 1560-1565. https://doi.org/10.5958/0974-360X.2015.00278.4

[23] Collee, J.G., Duguid, J.P., Fraser, A.G., Marmion, B.P. (1989). Practica Medical Microbiology. 3th Ed. Mackie and McCartney, pp. 54-55.

[24] Umesh, M., Mani, V.M., Thazeem, B., Preethi, K. (2018). Statistical optimization of process parameters for bioplastic (PHA) production by bacillus subtilis NCDC0671 using orange peel-based Medium. Iranian Journal of Science and Technology, Transactions A: Science, 42(4): 1947-1955. https://doi.org/10.1007/s40995-017-0457-9

[25] Law, J.H., Slepecky, R.A. (1961). Assay of poly beta hydroxy butyric acid. Journal of Bacteriology, 82: 33-36.

[26] Kulkarni, S.O., Kanekar, P.P., Nilegaonkar, S.S., Sarnaik, S.S., Jog, J.P. (2010). Production and characterization of a biodegradable poly (hydroxybutyrate-cohydroxyvalerate) (PHB-co-PHV) copolymer by moderately haloalkalitolerant Halomonas campisalis MCM B-1027 isolated from Lonar Lake, India. Bioresource Technology, 101(24): 9765-9771. https://doi.org/10.1016/j.biortech.2010.07.089

[27] Verlinden, R.A., Hill, D.J., Kenward, M.A., William, C.D., Radecka, I. (2007). Bacterial synthesis of biodegradable polyhydroxyalkanoates. Journal of Applied Microbiology, 102(6): 1437-1449. https://doi.org/10.1111/j.1365-2672.2007.03335.x.

[28] Reddy, A.R., Krupanidhi, S., Venkateswarulu, T.C., Kumar, R.B., Sudhakar, P., Prabhakar, K.V. (2019). Molecular characterization of a biopolymer producing bacterium isolated from sewage sample. Current Trends in Biotechnology and Pharmacy, 13(3): 325-335.

[29] Reddy, A.R., Peele, K.A., Krupanidhi, S., Prabhakar, K. V., Venkateswarulu, T.C. (2019). Production of polyhydroxybutyrate from Acinetobacter nosocomialis RR20 strain using modified mineral salt medium: A statistical approach. International Journal of Environment Science and Technology, 16: 6447-6452. https://doi.org/10.1007/s13762-018-2102-3

[30] Reddy, A.R., Venkateswarulu, T.C., Sudhakar, P., Krupanidhi, S., Prabhakar, K.V. (2018). Optimization of process parameters for Poly Hydroxy Butyrate Production from Isolated Acinetobacter nosocomialis RR20 through Submerged Fermentation. Current Trends in Biotechnology and Pharmacy, 12(2): 16-25.

[31] Reddy, A.R, Prabhakar, K.V., Venkateswarulu, T.C., Krupanidhi, S., Nazneen Bobby, Md., Abraham Peele, K., Sudhakar, P., Vijetha, P. (2020). Statistical optimization of PolyHydroxy Butyrate (PHB) production by novel Acinetobacter nosocomialis RR20 strain using Response Surface Methodology. Current Trends in Biotechnology and Pharmacy, 14(1): 62-69. https://doi.org/10.5530/ctbp.2020.1.7

[32] Reddy, A.R., Kumar, R.B., Vidyaprabhakar, K. (2017). Isolation and identification of Poly Hydroxy Butyrate (PHB) producing bacteria from Sewage sample. Research Journal of Pharmacy and Technology, 10(4): 15. https://doi.org/10.5958/0974-360X.2017.00193.7

[33] Tripathi, A.D., Srivastava, S.K. (2011). Kinetic study of biopolymer (PHB) synthesis in alcaligenes sp. in submerged fermentation process using TEM. Journal of Polymers and Environment, 19: 732-738. https://doi.org/10.1007/s10924-011-0324-2

[34] Silverstein, R.M., Bassler, G.C., Morril, T.C. (1991). Spectrometric Identification of Organic Compounds, fifth ed. John wiley and Sons, Inc., New York.

[35] Hong, K., Sun, S., Tian, W., Chen, G.Q., Huang, W. (1999). A rapid method for detecting bacterial polyhydroxyalkanoates in intact cells by Fourier transform infrared spectroscopy. Applied Microbiology and Biotechnology, 51: 523-526. https://doi.org/10.1007/s002530051427

[36] Silverstein, M.R., Francis, W.X., David, K.J. (2005). Spectrometric Identification of Organic Compounds, seventh ed. John wiley and Sons, Inc., Newyork.

[37] Lee, S.N., Lee, M.Y., Park, W.H. (2002). Thermal stabilization of Poly (3-hydroxybutyrate) by poly (glycidyl methacrylate). Journal of Applied Polymer Science, $\quad$ 83(13): 2945-2952. https://doi.org/10.1002/app.10318

[38] Reddy, A.R., Venkateswarulu, T.C., Johnbabu, D., Shyamaladevi, N. (2014). Homology modeling, simulation and docking studies of tau-protein kinase. Research Journal of Pharmacy and Technology, 7(3): 376-388.

[39] Khanna, S., Srivastava, A.K. (2005). Recent advances in microbial polyhydroxyalkanoates. Process Biochemistry, 40(2): 607-619. https://doi.org/10.1016/j.procbio.2004.01.053

[40] Valappil, S.P., Misra, S.K., Boccaccini, A.R., Keshavarz, T., Bucke, C., Roy, I. (2007). Large-scale production and efficient recovery of $\mathrm{PHB}$ with desirable material properties, from the newly characterized Bacillus cereus SPV. Journal of Biotechnology, 132(3): 251-258. https://doi.org/10.1016/j.jbiotec.2007.03.013

[41] Erceg, M., Kovacic, T., Klaric, I. (2005). Thermal degradation of poly (3hydroxybutyrate) plasticized with acetyl tributyl citrate. Polymer Degradation and Stability, 90(2): 313-318. https://doi.org/10.1016/j.polymdegradstab.2005.04.048 